\title{
Corona-19 Pandemic and the altering Dynamics of Human Resource Management: A Multifarious Approach
}

\author{
Mohammad Akmal Pasha a, Muhammad Zia-ur-Rehman ${ }^{\text {b }}$, Maria Kamran ${ }^{\text {c }}$ \\ ${ }^{a}$ PhD Scholar, Dept. of Leadership \& Management Studies, National Defence University, Islamabad, \\ Pakistan \\ ${ }^{\mathrm{b}}$ Associate Professor, National Defence University (Dept. of Leadership and Management Studies), \\ Islamabad Pakistan \\ Email: drziaofficial@gmail.com \\ ${ }^{c}$ MPhil Scholar, School of Economics, Bahauddin Zakariya University Multan, Pakistan \\ Email: mariaziaofficial@gmail.com
}

\begin{tabular}{ll}
\hline ARTICLE DETAILS & ABSTRACT \\
\hline History: & This study is an attempt to bring forth some of the human resource \\
Accepted 15 Dec 2020 & predicaments which will be ushered by the ubiquitous venom of the \\
Available Online 31 Dec 2020 & Corona Virus. Regardless of the deliberation operating at the back of \\
& Corona and the availability of the requisite vaccine, the executives need \\
& to adapt themselves with the new paradigm and contemplate on the \\
Keywords: & enactment of novel and apposite ways of managing human capital. The \\
Corona Pandemic, HRM, & global economy is feared to sink such that the world might be coerced to \\
Pakistan, Global Economy, & relive the 193o's global recession; thus each economy is entwined in the \\
Requisite Vaccine & cruel jaws of havoc. The study presents various dimensions of the \\
pandemic and then after the analytic discussion, puts forth some & $\begin{array}{l}\text { important suggestions for the reader that the resort lays in self-reliance, } \\
\text { caution and adaptability. Since the business activity is by and large a } \\
\text { I18,Fo1 }\end{array}$ \\
function of superior human capital, the HRM interventions need to be \\
the most commensurate ones.
\end{tabular}

(C) 2020 The authors. Published by SPCRD Global Publishing. This is an open access article under the Creative Commons Attribution-

NonCommercial 4.0

Corresponding author's email address: drziaofficial@gmail.com

\section{Introduction}

The HRM seems messed up in the event that the world economy has been jeopardized, like contracts related to shipping, transportation, construction, tourism, textiles, chemicals, automobiles, energy, and other industrial sectors maybe impacted. Some international law firms are also worried about the performance of Belt and Road Projects. In Pakistan, the infected population comprises of 64 percent males and 36 percent females. Unemployment may plunge devastatingly. According to International Labor Organization (ILO), there are 8.5 million domestic workers in Pakistan and this pool forms one of the biggest source of employment in the informal economy, a majority of whom are women and children and this renders HRM even more complicated. 


\section{Review of Economics and Development Studies, Vol. 6 (4) 2020, 919 - 929}

The commercial repercussions of corona are typical for a developing country like Pakistan. The growth in Pakistan's Gross Domestic Product (GDP) is expected to drop from 3.2\% to $2.4 \%$ due to COVID-19 outbreak, and growth in World's GDP drop is expected around 3.1\% to 2.8\%. Likewise, for G20 developed and emerging countries GDP growth in 2020 has been projected at $1.9 \%$ and $4.8 \%$ respectively, however after the COVID-19 break it is expected to drop to $1.3 \%$ and $3.7 \%$ respectively. Similarly, revenue shortfall is also in the looming, direct income taxation, Value Added Tax collections, and indirect taxes; in addition, by the same token decreasing trust among private and international investors will also contribute to widen the funding deficits. At factory level, there would crop up threats regarding wellbeing and life of the labor-class.

Travel trends have dropped by 60-70\% in Pakistan due to the fear of coronavirus, further in worst case scenario Pakistan tourism industry would face a US\$ 5.8 million losses. If luckily the world has recovered from coronavirus in coming months, the world might face disrupted global supply chains and this is feared that concentration of industries would develop in one country like in our neighborhood; China. Similarly China, is supposed to create opportunities of relocation of some of its industries to developing countries like Pakistan. The HRM concerning Global Supply Chain (GSC) would also be in hot waters.

So far in the hands of insufficient measures, the accommodation and food sectors have undergone a 10\% drop in production; more ghastly the entertainment and recreation sector production got dropped 6o\%, and publishing, communication and information sectors are expected to drop by $20.3 \%$. The transportation and storage sector would drop to $70 \%$, at the same time wholesale and retail would drop by $28.6 \%$, and electricity and air conditioning by $60.9 \%$. Likewise industries marked with high proportion of temporary jobs (e.g. restaurant, accommodation, and recreation sectors), would be though disproportionately affected by outbreaks, yet would lead to labor losses cutting on HR.

In the context of trade, according to Evansa (2020), in Pakistan the import duties have been waived on some 16 medical products for the period of 3 months (20/3 to 20/6). Exports of anti-malaria medicines and personal protection equipment have been banned, however exports of masks (except N95 \& PPE) and sanitizers have been authorized. Around US\$290 million cash subsidies have been given to export sectors in order to compensate for lost revenue. As a quick measure, more than 237 export units have been allowed to operate under preventive SOPs as imposed by the government.

Also that three months waiver on electricity bills for SMEs when they open up, cash assistance has been announced by government for the skilled labour losing their jobs due to lockdown. Pakistan has applied for debt relief offered by the G20 which will defer a payment of around \$1.8 Billion for Pakistan for one year. A US\$ 305 million loan has been finalized with the ADB of which 200 Million for social sector and 105 million has been earmarked for healthcare infrastructure support; for the month of April 2020. Pakistani exports registered a downward turn by US\$ 1 Billion ( $-54 \%)$ and imports down by US\$ 3.1 billion $(-34.4 \%)$. Agriculture is expected to see slow growth as the worst locust infestation in over 2 decades damages harvests of cotton, wheat, and other major crops. The government has declared a national emergency to combat the infestation. Modest growth is expected in some export-oriented industries such as textiles and leather. Pakistan has received commitment from multinational donors; like ADB - US\$ 2 billion; IMF - US\$ 1.38 billion; Islamic Development Bank - US\$ 650 million; European Union; US\$12.5 million. As industrial production and revenues have declined, the US\$6.7 billion support programme has been launched by the government to assist the poorest sections of the country (mainly unskilled labour). FDI inflow has soared by 62.5\% year on year in the first half of 


\section{Review of Economics and Development Studies, Vol. 6 (4) 2020, 919 - 929}

FY2020. Short-term capital has also poured in rapidly to buy government securities denominated in Pakistan rupees that offer attractive returns. Supported by these flows, international reserves are expected to improve to 2.2 months of import coverage at the end of FY2020. Collaboration between Pakistani and Belgian companies in the development of pharma products, hospital and medical equipment (diagnostics, electro-medicals, support products, etc.) is also underway.

As put by Ahmad (2020), with an exception of food manufacturing, export-oriented industries and those connected with the construction sector, all other types of enterprises would face mass dismissals, and job disruptions to the tune of 21 million workers. The paradoxical would be the situation characterized by cheap and redundant HR but squeezed business opportunity for the firms acutely engaged in HRM. While Government has initiated social transfers paying PKR 12,00o to more than 18 million households, employment retention has been ensured only through administrative orders and a refinancing scheme to enterprises (for wage payment). A relief package has earmarked amount of PKR 200 billion to provide relief to daily wage workers.

The COVID-19 impact on the Pakistani economy is estimated to range between $0.8-1.3 \%$ of the GDP and $1 \%$ in 2021. Imports are estimated to decrease by $50-60 \%$, and exports by $10-20 \%$ while the employment loss is estimated at $20 \%$. All of the macroeconomic targets stand the risk of being missed out. The economy is expected to shrink to negative $1-1.5 \%$ against an expected growth rate of $2.4 \%$ during the current fiscal year. The tax revenue target has also to be revised to US\$24.5 Billion, down by $19 \%$.

This is also being projected that Pakistan's economy will experience negative GDP growth of $1.3 \%$ in $2019-20$, followed by only $1 \%$ growth in the coming year 2020-2021. In other words this implies that our GDP growth in the last quarter of 2019-2020 will be a big negative $10 \%$. The other sign of the coin could be a decline in exports, private investment and household consumption spending. The ongoing lockdown and the subsequent fall in the economic activity could lead to unemployment of over 5 million more workers. This will push the unemployment rate to an unprecedented degree of $4 \%$, which will suppress the poor below the poverty line to the tune of million, finally the overall pool of poor would extend to10o million, hence the HRM would become excessively ticklish.

The total external debt of Pakistan as of first quarter of 2019 stood at $\$ 105$ billion coupled with rupee depleting drastically against dollar. By May 2019, the Pakistani rupee had drooped to a year-onyear manifesting depreciation of 30\% vis-a-vis the US dollar. On the whole, the year 2019 along had added the debt of over $\$ 13$ billion, which is over $40 \%$ of the total debt added in last 10 years. The inflation rate in Pakistan has surged to $12.93 \%$ which is highly alarming and it is indicative of even gruesome degree to which it will plunge. The FBR estimates that the lockdown of only Karachi would cause tax losses up to Rs. 380 billion. The daily wagers which cover 47 percent workforce in service sector (such as marriage halls, hotel industry and others belonged to this sector) will be severely struck. The tourism industry would bear loss of at least Rs. 40 billion, merely in the wake of the disrupted

Global Value Chain (GVC). So the HR managers concerned with such sectors will face hard circumstances.

Regarding microfinancing, the research findings of Malik, Meki and Morduch (2020) are based on 'rapid response' phone surveys of about 1,00o microenterprise owners, a survey of about 200 microfinance loan officers, and interviews with regulators and senior representatives of microfinance institutions. The COVID-19 pandemic jeopardizes local microfinance institutions in Pakistan, a country which is studded with mature microfinance sector serving a large number of households. They find that 


\section{Review of Economics and Development Studies, Vol. 6 (4) 2020, 919 - 929}

on average, week-on-week sales and household income both fell by about 90\%. Households' primary immediate concern in early April, 2020 happened to be how to secure food, $70 \%$ of the sample of current microfinance borrowers were not able to repay their loans; while the loan officers anticipated a repayment rate merely $34 \%$.

The HR managers operating on the school-education front, the lockdown has cast varied effect on schools, for example some of the elite English-medium schools are in the process of developing virtual school and Chrome-books, while public sector and low-income private schools seem oblivious. One option could be the cellular phones, where according to the 2018-19 Economic Survey, $89 \%$ of Pakistanis have access this facility whereas connectivity remains a predicament. Hassan and Attique (2020) Pakistan's students in the face of poor access to TV and the internet further compound these difficulties. A straightforward option is provision of widespread internet. At the middle, high and higher secondary level, the out of school children amount to respectively 6.5 million, 5 million and 6.3 million. The drop outs rarely go back to school, especially girls. Female students of age-group 10 to 14 years, spend more time on learning during weekends than boys do, the age group 15 to 19 years, the relationship reverses. Further about 50\% of girls of both age-groups consume between o to 3.5 hours on studies per day, with a median of 1.75 hours. In contrast, boys in the age-group 10-14 years, 50\% spend o to 3 hours per day studying, age group 15-19, o to 4 hours per day, but the median value is much lower at 1.5 hours.

Work-at-home option is too oblique for a developing country like Pakistan. Hassan and Attique (2020) benefitted from the 2018-19 Pakistan Social and Living Standards Measurement (PSLM), a nationally representative household survey and found that only $10 \%$ of jobs in Pakistan had a nature that allowed individuals to carry on from home. Rates further dwindle in case of rural inhabitants as they happen to be low-skilled-low-paid, similar is the issue of service industries.

\section{Literature review}

Hassan and Attique (2020) the novel COVID 19 Corona virus has been less fatal compared with the Pandemic of 1918 Spanish FLU. Researchers believe that President Wilson's (effected by Spanish FLU virus in 1918) impairment rendered Treaty of Versailles harsher which caused the world war II, the Corona Pandemic carries a couple of symptoms of repeating the history. In the words of Khalil, Ali, Tanveer, Ovais, Idrees, Shinwari, and Hollenbeck (2017), over the past few decades, Pakistan has suffered a great deal from infectious diseases such as dengue, Crimean-Congo fever, hepatitis, measles, and polio. Changing climate conditions, environmental degradation, global warming, loss of biodiversity, and other ecological determinants have cast a direct effect on these diseases and have

resulted in the emergence and reemergence of infectious entities. Below is a brief description of different viral disease which have proved problematic in Pakistan during last couple of decades.

\subsection{Dengue Virus}

Dengue virus, which is now characterized as an emerging infection, affects from 50 million to 100 million people globally, causing an estimated 24,00o deaths per year. Dengue virus first appeared during World War II and was reported to have expanded in Asia after the 1980s. It is classified into 4 serotypes: DEN-1, DEN-2, DEN-3, and DEN-4. Viral transmission is brought about by the vector Aedes Aegypti mosquito. Although a tetravalent dengue vaccine has recently been registered, the diagnosis time will still remain critical for patient management. Dengue fever may be characterized as classical dengue fever, dengue hemorrhagic fever (DHF), or dengue shock syndrome (DSS). Pakistan has had a history of recurrent dengue fever outbreaks since the 1980s. However, it was first documented in 1994 and considered endemic to Pakistan and other neighboring countries. Outbreaks are reported 
Review of Economics and Development Studies, Vol. 6 (4) 2020, 919 - 929

frequently in the monsoon season-that is, the season of heavy rainfalls, which provide an environment conducive to the virus to propagate, causing hemorrhagic fever.

\subsection{Measles Virus}

Measles is a contagious but vaccine-preventable viral disease that mostly affects the respiratory tract (febrile respiratory prodrome); the most general symptoms include maculopapular rashes, cough, and fever, which may lead to death. After global initiatives in the previous decade (2000- 2011) to combat measles, the disease prevalence dropped significantly (up to 71\%), and mortality rates dropped to just 1 per 1,0oo. About 95\% of measles deaths occur in low-income countries. Measles eradication programs like the Global Measles and Rubella Strategic Plan (2012-2020) represent a success story, but specific circumstances in Pakistan make measles eradication challenging. In different outbreaks of measles, there were 4,000 and 14,000 ( ${ }^{*} 1,000$ cases/million population) confirmed cases in 2011 and 2012, respectively, resulting in deaths of 238 people. In 2013, a total of 321 people were reported to have lost their lives to measles in Pakistan.

\subsection{Crimean-Congo virus}

Crimean-Congo Hemorrhagic Fever (CCHF) or simply Congo Virus is another deadly pathogen that is prevalent in certain parts of Africa, Europe, Asia, and the Middle East; it has a mortality rate ranging between 3\% to 30\%. Crimean Hemorrhagic Fever (CHF) first became evident in 1944 in the former Soviet Union. The disease mostly affects farmers and people living in close proximity to livestock. In a recent outbreak in Turkey, 90\% of the infected individuals were farmers. Congo virus is associated with Ixodid Ticks (Genus Hyalomma), its natural vector. It was first reported in Pakistan in 1976. Sporadic cases and mini-outbreaks of CCHF have been reported in certain parts of Pakistan, including Rawalpindi, Abbottabad, Kashmir, Peshawar, Karachi, and some parts of Baluchistan. However, about 40 to 60 cases have been reported annually since 2000. Data from the Disease Early Warning System (DEWS) reported 49 confirmed cases of Congo hemorrhagic fever in 2012; 6o infected individuals were reported in 2013. Increased awareness, rapid diagnosis, proper training of healthcare workers, and community-based infection control measures can be effective tools to prevent Congo virus outbreaks.

\subsection{Polio Virus}

Although polio virus has been eradicated from the rest of the world, the disease continues to be reported in Pakistan, Nigeria, and Afghanistan. The virus is mainly transmitted by oral-fecal and sometimes by oral-oral route. It invades the nervous system and can lead to paralysis in the infected individual within a few days. Polio virus can be found in sewage water from the affected area and can be transmitted through infected respiratory secretions and sneezing. Pakistan is still struggling to eradicate polio infections due in part to political instability and to some social and religious misconceptions. Until 2005, the incidences of polio infection were declining, and the vaccination campaigns were quite effective. However, in 2009, 89 poliomyelitis cases were reported in Pakistan. The number increased to 144 and 198 in 2010 and 2011, respectively. The highest number of poliomyelitis cases was 306 in 2014 in 44 districts of the country. Extensive vaccination and environmental sampling, accompanied by massive awareness campaigns in these target areas, resulted in a decreased number of cases (a total of 22) in 2015. It is hoped that these polio eradication programs will soon eradicate the disease from the country.

\subsection{HIV-AIDS}

Human Immunodeficiency Virus (HIV, a lentivirus from the Retroviridae family of viruses) is the causative agent for Acquired Immune Deficiency Syndrome (AIDS), which attacks the immune cells of 


\section{Review of Economics and Development Studies, Vol. 6 (4) 2020, 919 - 929}

the infected patient, resulting in a decline in $\mathrm{CD}_{4} \mathrm{~T}$ cells. It is estimated that $<0.1 \%$ of the Pakistani population has been reported to be infected with HIV; however, the incidence is high among sex workers, especially when they interact sexually with injection drug users. Overall, these data indicate that HIV infection in the general population has remained constant (0.01\%) over the past 2 decades. Awareness programs and stringent surveillance targeting high-risk groups will be helpful in controlling infection in the future.

\subsection{Hepatitis C Virus}

According to WHO, about 130 to 150 million people are affected by hepatitis $\mathrm{C}$ virus. A significant number of those people develop chronic liver disease, and an estimated 500,0oo die each year globally. Hepatitis $\mathrm{C}$ virus (HCV) has wide genetic diversity and variations from region to region based on prevalence of its different genotypes. Globally, genotypes 1 and 3 are most common. Hepatitis viral infections are highly endemic in Pakistan, with hepatitis B and C being a major disease burden with maximum mortality. Prevalence of $\mathrm{HCV}$ is around $5 \%$, with an estimated 10 million infected individuals in Pakistan. Six genotypes have been identified, with genotype $3(74 \%)$ as the most prevalent. Phylogenetic analysis based on the full-length HCV genome revealed that the HCV-a prevalent in Pakistan is genetically distinct from those prevalent in the rest of the world.

\subsection{Avian Influenza Virus}

Avian Influenza Virus represents a major threat to the country's economy, as it can cause infection in humans, birds including poultry, horses, and pigs. The poultry industry constitutes a major portion of the country's economy. Since 1995, there have been 5 epidemics of avian influenza reported in Pakistan, including subtypes $\mathrm{H}_{7}, \mathrm{H} 9$, and $\mathrm{H}_{5}$. An epidemic of $\mathrm{H}_{7} \mathrm{~N}_{3}$, a highly pathogenic avian influenza (HPAI), emerged in scattered areas across the country and lasted for about 4 months. In 1998, an outbreak of $\mathrm{H}_{5} \mathrm{~N} 2$, a Low Pathogenicity Avian Influenza (LPAI), appeared in broiled chickens and poultry. Similar outbreak of $\mathrm{H}_{7} \mathrm{~N}_{3}$ emerged in 2000. In 2003-04, the epidemic of $\mathrm{H}_{7} \mathrm{~N}_{3}$ resulted in severe economic devastation. During the same epidemic, H9N2 was also found in some of the flocks, resulting in a mortality of $70 \%$ to $80 \%$ in the affected flocks. Avian influenza viruses isolated from poultry in Pakistan (in 1998-99) were found to be closely related to H9N2 viruses that caused human infections in Hong Kong. Constant surveillance and vaccination programs are recommended for preventing future bird flu influenza infections in the country.

\subsection{Swine Flu Virus}

Influenza viruses have been emerging and reemerging over the past 3 decades, with novel strains of pandemic potential circulating globally. The first outbreak of H1N1 (swine flu) occurred in 2009 in Mexico and spread to several other countries. In Pakistan, the first case of swine flu was confirmed on June 18, 2009. There were a total of 1,242 suspected cases, with 262 laboratory-confirmed cases and 29 deaths reported. But the 2009 swine flu pandemic appeared to be of lesser concern in Pakistan compared to other affected countries. However, an epidemic of swine flu in India (December 2014 to early 2015) was followed by another one in central Pakistan, resulting in an estimated 16 deaths by January 2016. Continued surveillance and mass awareness are important to overcome the disease.

\subsection{Ebola Virus, Zika virus and MERS}

Besides the endemic entities, there is a global threat of Ebola virus that demands serious and dedicated efforts to be undertaken at federal and provincial levels, with effective participation from civil society and religious scholars. Zika virus is among the heavily debated issues across the world. Recent statements by the health ministry and WHO indicated that the risk of a Zika virus outbreak is insignificant. Even if there is a low risk, there is a great need to monitor the virus globally and respond 


\section{Review of Economics and Development Studies, Vol. 6 (4) 2020, 919 - 929}

immediately if a suspected Zika case is found in the country. An outbreak response and implementation strategy should be immediately developed against pathogens like Ebola, Zika, and MERS (Middle East Respiratory Syndrome).

According to Waris, Atta, Ali, Asmat and Baset (2020), COVID-19 outbreak was first time experienced in the Wuhan City of China at the end of December 2019, which spread rapidly in China and then fanned out world-wide embracing 209 countries of regions like America, Europe, Australia and Asia; undoubtedly including Pakistan. The life is resembling the plight that was once ubiquitous one hundred year ago. Like a poem was written by Kathleen O’Mara during Spanish Flu in 1919 (Bakhtiar, 2020) a few line are reproduced below:

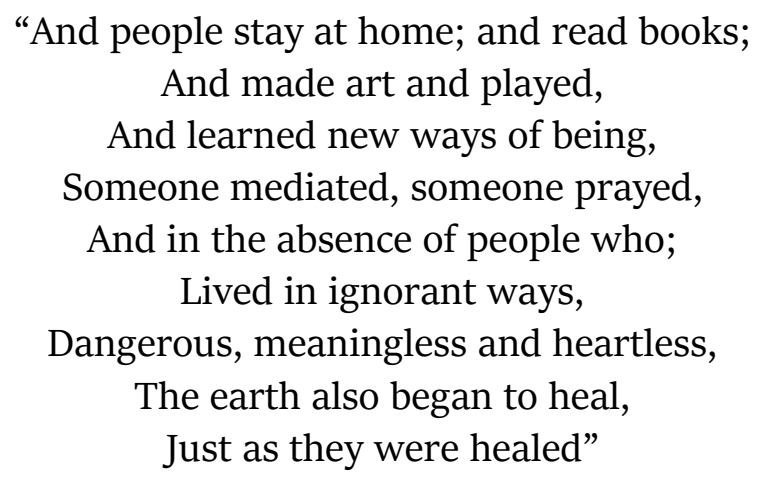

The havoc could be global, which will ultimately converge to HRM predicaments cascading its effect the respective stakeholders. In view of Raja (2020), Cuba, Venezuela and Iran under harsh sanctions from USA, and Pakistan as undergoing a plight this is feared the great depression of 1930's repeats itself. What bred corona virus is still riddle, as Raja (2020) put it, the conspiracy theories are tinkering in between, moving along the pendulum where China and USA seem self-consumed in blamesharing, Iran accusing USA for foul play plotted against Iran, the corona affected nations lamenting that it is linked with $5 \mathrm{G}$ technology, since to them where ever the $5 \mathrm{G}$ technology has been installed the virus has spread comparatively at a burgeoning pace. As a reaction, the anti-Dajjalis are catapulting infrastructure where $5 \mathrm{G}$ technology has been fanned out in the world. To move forward, on one hand while Israel claims that it has invented vaccine for corona, Bill Gates declares that social life around the globe can never become normal until each individual of the world is not vaccined, especially then human capital that is the human resources. According to Raja (2020), corona virus can be viewed through the lens of Bio-Weapon as well. He maintains that though Soviet Union and European countries had abandoned creation of bio-weapons during 196os and 1970s and then signed the pact called BioWeapon \& Toxin Convention (BWTC) in 1972, yet clandestine production kept on lingering. For example Sarin bio-gas was deployed by Iraq against the Iraqi Kurds and also against Iran, then by Israel in Syria and by India in J\&K. Still, it is estimated that over 800 US military bases are yet secretly engaged in research on bringing novelty in bio-weapons.

As put forth by Javed (2020), COVID-19 crisis would leave some 25 million unemployed in Pakistan and would push millions towards hunger and poverty that would resultantly degenerate human resources. The global economy projection is $2.9 \%$ to $2.4 \%$ while China's economic forecast has been downgraded from $6.1 \%$ to $4.9 \%$. The European Union will be hugely affected incurring a trade loss of \$15,597 million. The first comes United States with trade impact of \$ 5,779 million. India falls among top 15 affected countries with trade impact of \$ 348 million.

The slowdown in Chinese economy through transcended effect of global value chain will affect 


\section{Review of Economics and Development Studies, Vol. 6 (4) 2020, 919 - 929}

Pakistan and the most impacted sectors would be textile and apparel facing a loss of \$ 44 million. Calculated on the basis of decrease in GDP growth contraction in services sector, would cause revenue loss and decrease in trade and remittances, the initial loss to Pakistan’s economy would surge to Rs. 1.3 trillion. The loss to agriculture and mining sector would range between \$ 1.5 billion and \$ 16.23 million, business trade, personal and public services between $\$ 1.94$ billion and \$ 5.54 million, light and heavy manufacturing between \$ 671 million and \$ 3.6 million, transport services between \$ 565.6 million and \$ 0.92 million, hotels and restaurants between \$ 253.7 million and \$ 0.67 million, total between \$ 5 billion and \$16.23 million. The job losses would be around 9,46,0oo whereas GDP would drop by around $1.57 \%$ and would frustrate human resource pool. Live animals export declined from $\$ 68,9982$ thousand in January 2020, to $\$ 60,938$ thousand in February 2020, tourism receipts increased from $\$ 79$ million in 2016 to $\$ 85$ million in 2017 and would steep further. Pakistan's travel services based on business and personal travel increased from \$247.1 million in FY 19 to \$320.3 million in FY 20 showing growth of 29.6\%. The remittances increased from $\$ 14,355.8$ million in FY 19 to \$15,126.6 million in FY 20 showing growth of $5.4 \%$, still $10 \%$ to $20 \%$ decline will take place in remittances in coming months. According to the sentimental analysis undertaken by Asma, (2020), globally, the elements of anticipation, and trust and both could be correlated with religiosity. The enhanced menace of domestic abuse and violence is another potential consequence as sensed by the United Kingdom, China, France and other countries.

\section{Analytical Explanation and Construal}

According to HEC Covid-19 Policy Guidance No.5 (Online Readiness), the HRM should focus vectored towards the standards related with measuring universities' online readiness cover 8 major areas, for example the university, the course, the faculty, the library, the technology, the examination, the laboratory, and the student. The University's HR management and general management looking after educational materials and personnel should be professional. Three components like existence of an explicit policy and SOPs for approval of courses, a Learning Management System (LMS) to take care of information, track progress, and coordinate activities, and governance system for the purpose of decision-making and more specifically adjudication of complaints. The governing system like Online Academic Council (OAC) has to be in place. For Course, the following areas must be taken care of: the course introduction, the learning objectives, the evaluation/ grading policy, course prerequisites, course requirement or rules, the textbooks or other required readings, the key dates, the time and venue (physical or virtual) of class meetings, the lesson plan and PPTs or handouts. In terms of Faculty special attention needs to be paid to challenges, opportunities, techniques, and supportive resources with respect to online classes. For Library: all the required readings and associated materials (optional readings, audiovisual materials, or literature or data needed for course-related research) should be made available through. In terms of Technology, the technological packages including the software for classroom meetings (e.g., Microsoft Teams, Zoom, Google Classroom, etc.) are needed. Students should be facilitated with great internet connectivity. The imperatives for evaluation and assessment include exams, assignments, in-class activities, self-assessments, evaluations, for Laboratory and Practical Instructions an imperative system is the prerequisite. HEC has also delineated six factors that may determine if a particular course is ready for online delivery which include university's management system (including HRM), the course itself, the faculty member, the library or resource bank, the technological infrastructure, and the readiness of the students.

The HRM in the field of real estate needs to engage itself in multifarious interventions. The constructors for example would need to construct small houses instead of big ones and add gardens. At the same time they will have to maintain additional cleanliness. Internet companies have tremendous business ahead, they need to go for $4 \mathrm{G}$-adaptation at a faster pace, develop new packages, offer free 


\section{Review of Economics and Development Studies, Vol. 6 (4) 2020, 919 - 929}

bundles of internet and apps develop mechanism to make sure that home- delivery of goods and services is made possible. This implies that the small shopkeepers need to attach themselves with internet companies. There will emerge huge business opportunities for wholesalers \& distributors, the new era would cause elimination of middlemen or even wholesalers while retailers will take up the role of middlemen. Especially the high tech companies will have huge business chances. The HRM at cargo companies will have to change their way of business.

For HRM at banks, a greater need for more efficient ATM system and other online business methods would emerge. The professionals like drivers and mechanics have great chance, businesses will need their services to enhance their trade. Managers will lag behind and the real deliverers will surpass. As new types of businesses will emerge, the nature and functioning of international economy will change that will insinuate dynamism in local economies as well. The HRM at hotels will need to develop separate rooms with hygienic maintenance instead of the sharing rooms or dormitories.

The households would have to establish enhanced solidarity, compassion, love, respect and dignity, and will notice that only true and real relations will go a long way. They at the same time will avail of huge opportunities, like digital marketing, teaching online etc. Masses will need to turn their hobbies into earnable skills- enhance earn ability. People will have only option to live with good and trustworthy persons; will be careful in finding new friends which could be contagious.

The HRM engaged in developing recreational equipment will have to focus on home-based exercise machines, games, recreations, and exercise kits. Similarly, home cleaning operatus will be more common, so the manufacturers have great opportunity. Similarly, the HRM engaged with massrelated recreational activities and running like clubs, cinemas, swimming pools, and gyms etc. will have to shrink, and would redirect these services to be usable at household level. The companies will have to develop such equipment and apps which are helpful in offering repair work at home for electronic appliances, cars and bikes and etc. The households will become more adept in furnishing homemade embroidery items, bakery confectionaries, tailoring, and will use own vehicles for offering home delivery to customers.

The HRM busy with security systems will face new threats. There could be assault on human health, life may not seem safe even in drawing room, the governments will be too busy in safeguarding their thinkers, scientists, and professors. There would be great tussle when it comes to be issue of obtaining, retaining and maintaining human resource, simply the states will vie for superior human resources, which is the intellectual capital. Hence the nations that are poor at this frontier will be left behind.

The HRM concerned with spiritual and religious organizations, will face that masses not have lesser trust on religious healers, especially the fake enterprises or spiritual healers will vanish. People will be more practical, superstitions will be wiped away, greater faith in God will get promoted. Thus the emerging philosophy will be 'caring self and save others' hence the spiritual practices will be common at individual level.

\section{Discussion}

The deteriorating human capital marred by destitution and resource-starvation would leave the society with nothing but a demoralized human resource, dropping thereby the HRM at an alien island surrounded with turmoil laden with varied challenges. Corona might plunge around 11m people in Asia to dip into poverty, and one may deduce that societies in this region might face rising crime, political 


\section{Review of Economics and Development Studies, Vol. 6 (4) 2020, 919 - 929}

instability and social unrest more emphatically so when seen in the backdrop of the fact that $33 \%$ of workers earn US \$ 2 per day from an informal work.

Massan, Sheikh and Dahri (2020) report that the 177 universities of Pakistan have more than 12,000 faculty holding $\mathrm{PhD}$ degrees and on an average about $1500 \mathrm{PhD}$ scholars are added per annum. For one faculty at the sampled university out of 18 research faculty, almost $16 \%$ supervisors had developed contact with research candidate. On the other hand, out of 17 students registered to these supervisors, $41 \%$ had kept the project on track and meeting time-lines. Again $89 \%$ of the established online meetings could be conducted through WhatsApp, and calls, whereas the remaining were used for zoom meetings to be used for detailed discussion and analysis of results. Massan et. al. suggest that universities ought to appointment a focal person to look after all research related activities, all people entering the university premises must put on masks, apply sanitizers and must be screened for body temperature, minimize academic loss to student through superior co-ordination, furnish requisite Integrated Software, formulate SOP's and formats help establishment of clear chain of command, grade visibility to the student at different levels, effectuate availability of standardized templates for assessment of various theses, announce of marks distribution, initiate online presentations for creating industry exposure and linkages, present up dated research on the Coronavirus pandemic through forward looking office of industrial liaison, online training on software packages such as reference managers and SPSS, Smart-PLS, MATLAB, Minitab etc. Thus the professionally trained HR will be an uphill task for the managers.

Mahmood (2020) suggests that government should increase social spending, lower interest rates, stabilize exchange rate, provide credit lines for the timely payment of company payrolls and seek international and regional cooperation in all aspects of the economy. Pakistan should immediately arrange and avail IMF-World Bank facility to postponement of debt payment. Government has reportedly reached IMF for $\$ 1.4$ billion new loan.

Focus more on trading with China as it has started its rehabilitating phase more vigorously, income loss in China should provide an opportunity for Pakistani exporters to sell their low quality products that will be more in demand in China. China is now back to business and has taken certain policy measures. For instance, it has increased export tax rebates for its exporters that have started putting out Pakistan's export orders at risk, some have already been cancelled. Our government needs to take new and effective measures to counter such moves by China and others, the enterprises nevertheless desperately need professional HRM.

European Union has relaxed certification rules for the import of fruits, vegetables and other food items to ensure good supplies of such items in their domestic markets. Pakistani exporters of food items, vegetables and fruits need to benefit from this rules relaxation and rising prices in EU. Pakistani exporters should also capitalize the opportunity that is coming from increased demand for medical instruments, health clothing, pharmaceutical products, bed linen, towels, and simple garments and clothing. All of these are normally produced by the Pakistan industry. But all of these require that supply chains domestically and globally be kept intact. Javed (2020) observed the possible projections estimated 20,000 to 456,000 positive cases within 80 days of disease spread in Pakistan. Not sparing HRM even at hospitals, the Corona predicament has changed the complexion of the functionality of all elements pervading the globe.

\section{Conclusion}

With Corona virus playing havoc at an ever increasing rate, the world is simply at the mercy of 
Review of Economics and Development Studies, Vol. 6 (4) 2020, 919 - 929

Nature or the scientists who may develop vaccine for it. The conspiracy theory scares individuals regarding the deliberation of this virus and at the same time with a greater degree that the vaccine had been developed beforehand or at least it exists right-now and the blood-suckers business enterprises are just eyeing at the opportune moment to encash the agony of the bewildered and perplexed humans. Pakistan being a poor country needs to take commensurate measures and the masses at the same time must take Corona seriously internalizing thereby the theme that prevention is the best cure. The new dynamics have dictated adjustments at all levels should each one of us aspire to spend a happy, prosperous and secure life.

\section{References}

Ahmad. Iftikhar. (2020). COVID-19 and Labour Law: Pakistan, Italian Labour Law e-Journal, Special Issue 1, Vol. 13 (2020), ISSN 1561-8048

Bakhtiar. H. (2020). Better Morrow, Sector C, Phase 1, DHA, Islamabad, issue 57, p. 6

Chohan, Usman, Dr. (2020). Forecasting the Economic Impact of Coronavirus on Developing Countries- Case of Pakistan, Working Paper ID: EC016UC March 28th, 2020 Available on the Social Science Research Network (SSRN)

Evans O. (2020). Socio-economic impacts of novel coronavirus: The policy solutions, BizEcons Quarterly, 7, 3-12.

Hasan, Rehman \& Zhang. (2020). Disparate Impacts of COVID-19 Lockdowns in Pakistan, Affecting Girls and Rural Residents. Working Paper Number 20010, Lahore University of Management Sciences, downloaded from: https://lib.dr.iastate.edu/econ_workingpapers/105

How the necessary economic support measures can cushion the corona crisis and accelerate the ecological transition. (2020), Policy Brief (03/2020), On Behalf Of Greenpeace Germany

Hyder, A. (2020). Short Notes On The Economy During The Covid-19 Crisis, Vol. Iii, April 5, 2020

Javed, Asif. (2020). Policy Review: Economic Impact of Coronavirus and Revival Measures: Way Forward for Pakistan, SDPI

Khalil, A. T., Ali., M., Tanveer, F., Ovais, M., Idrees, M., Shinwari, Z.,A., \& Hellenbeck, J., E. (2017). Emerging Viral Infections in Pakistan: Issues, Concerns, and Future Prospects, Health Security, Volume 15, Number 3, $2017^{\text {a }}$ Mary Ann Liebert, Inc.

Mahmood, Zafar, Dr. (2020). COVID-19 and Pakistan's trade prospects, School of Social Sciences and Humanities National University of Sciences and Technology, Islamabad

Malik, S.A.; Javed, A. (2020). Forecasting Unusual Trend of COVID-19 Progression in Pakistan. Preprints 2020, 2020040504 (doi: 10.20944/preprints202004.0504.v1)

Malik. Kashif, Meki. Muhammad \& Morduch. Jonathan. (2020). COVID-19 and the Future of Microfinance: Evidence and Insights from Pakistan. Timothy Ogden, ISSN: 2695-2246

Massan, Shafiqur Rehman, Sheikh, Muhammad Mujtaba \& Dahri, Abdul Samad. (2020). Effect of Covid-19 epidemic on research activity of researcher in Pakistan Engineering University and its solution via technology

Raja, Brig., Asif, Haroon. (2020). Better Morrow, Sector C, Phase 1, DHA, Islamabad, issue 57, pp. 7, 10-14

The COVID-19 Pandemic in the Middle East and North Africa, (2020). The Project on Middle East Political Science (POMEPS), Institute for Middle East Studies, George Washington University

Waris. A., Atta. U,K., Ali, M., Asmat, A., \& Baset, A. (2017). COVID-19 outbreak: current scenario of Pakistan, Health Security, Volume 15, Number 3, 2017 